\title{
LOCAL WISDOM VALUES GOVERNANCE AS NON-FINANCIAL INTANGIBLE ASSETS IN SUPPORTING INDIGENOUS PEOPLES' SUSTAINABILITY IN KAMPUNG PULO KABUPATEN GARUT
}

\author{
Abin Suarsa $^{1}$; Verawaty ${ }^{2}$; Toto Sugihyanto ${ }^{3}$
}

\section{0}

${ }^{1,2,3}$ Accounting Dept., STIE

Muhammadiyah Bandung,

40262, Indonesia

Korespondensi:

Email:abinsuarsa@stiemb.ac.id

Artikel ini tersedia dalam:

http://journal.stiemb.ac.id/index .php/mea

DOI: 10.31955/mea.vol3.iss1.pp19-28

Vol. 3 No. 1 Januari-April 2019

e-ISSN: 2621-5306

p-ISSN: 2541-5255

\section{How to Cite:}

Suarsa, A., \& Verawaty, V.

(2019). LOCAL WISDOM

VALUES GOVERNANCE AS

NON-FINANCIAL INTANGIBLE

ASSETS IN SUPPORTING

INDIGENOUS PEOPLES'

SUSTAINABILITY IN KAMPUNG

PULO KABUPATEN

GARUT. Jurnal IImiah MEA

(Manajemen, Ekonomi, \&

Akuntansi), 3(1), 19-28.

Copyright (c) 2019 Jurnal Ilmiah MEA (Manajemen, Ekonomi, \& Akuntansi)

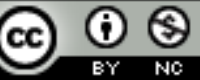

This work is licensed under a Creative Commons Attribution-NonCommercial 4.0 International License
ABSTRACT:The study entitled " Local Wisdom Values Governance as Non-Financial Intangible Assets in Supporting Indigenous Peoples' Sustainability in Kampung Pulo Kabupaten Garut " aims to understand the motivation of indigenous peoples Pulo village in implementing local wisdom in life everyday so as to support its sustainability.

The method used in this research is qualitative method with interpretive paradigm and phenomenological approach. The analytical unit focuses on awareness, noema, noesis, intuition, and intersubjectivity. The main data of this research are interview result and observation result.

The results of this study indicate that the local wisdom of the pulo community contains the philosophy of life and the teachings that prioritize the balance between human, God, and nature. Governance emphasizes exemplary, communication, education, and mutual reminders.

Keywords- Governance, Local Wisdom, Sustainability, Phenomenology, Indigeneous Peoples'

\section{Introduction}

Indigenous village is a village inhabited by traditional society, where the pattern of life and daily life of the people still uphold the customs inherited by the ancestors and has its own distinctive. One group of indigenous peoples who are able to maintain and uphold the customs inherited by the ancestors is the indigenous Kampung Pulo people found in Garut regency of West Java Province. Pulo village is located in an island-shaped area in the middle of the lake named Situ Cangkuang (Ramdianti, Hidayah, and Widiawati, 2013).

The Pulo village was built by Mbah Dalem Arief Muhammad in the 17th century (Hidajat, Fatharani, Martika, Andika, and Putih, 2014). Within that period, 
people are able to maintain the customs and culture that are the wealth of the community.

Intangible assets are seen as valuable assets in both profit-oriented and non profit oriented organizations that include values that can acceptance and norms reflected in the interaction between individuals of any society, company or organization (Mahdalena, 2016). Just as an accounting study using social analysis (sociology) based on an interpretive paradigm is an attempt to bring the science of accounting closer to the cultural, religious and spiritual realities (Mahdalena, 2016). So in the assessment of asset management management with social analysis also seeks closer management science to the same reality.

This research is motivated from previous research on indigenous people of Kampung Pulo which has been done by some researchers on the maintenance of wood and bamboo material done by Hidajat, Fatharani, Martika, Andika, and Putih (2014), Islamic culture in kampung pulo community by Syukur (2016), sustainability of Sundanese culture by Saringendyanti (2008), vernacular house of South West Java in response to earthquake by Triyadi and Harapan (2008), and ethnobotany of indigenous people of Kampung Pulo by Ramdianti, Hidayah and Widiawati (2013) from these studies the subject of research is still in the context of the management of fixed assets, has not touched the aspect of intangible assets that play a role in the management of fixed assets. What makes this research interesting is the exploration of awareness of the values of local wisdom that is holistic so that it can be used to build the concept of science in the management of asset management that is not only financially. The values of local wisdom is always maintained its existence and become the most important asset in the development and sustainability of the organization.

The purpose of this research is to know deeper the Indigenous People Kampung Pulo and local wisdom in maintaining its existence in supporting its continuity.

\section{Literature Review}

Assets are everything tangible and intangible that has economic value and economic life to support the organization in providing services (Ouertan 2008). Managing assets effectively and efficiently in achieving organizational objectives is known as Asset Management, which continues in this study called asset management.

Danylo (1998) defines asset management as a methodology for allocating resources efficiently and correctly to achieve organizational goals. $\mathrm{He}$ further explained that asset management is a way or approach to do something to solve a problem or situation.

According to Ouertan et al., (2008), asset management is the process of organizing, planning and supervising purchasing, using, maintaining, repairing and / or eliminating physical assets to optimize potentials service delivery and minimizing risks or costs life-related assets using assets intangible such as-based decision applications knowledge and business processes.

Many terms related to Intangible Assets such as intellectual Assets, Intellectual Assets Management, Intellectual Capital, Intellectual Capital Accounting, Intellectual Property, Intellectual Property Right, and others. Simply put by Sole (2010), Intangible Assets is the value of a company that describes the company's intangible assets. Further characteristics of Intangible Assets by Single (2010) include: (1) lack of physical existence; (2) Not a financial instrument; (3) Long-term nature.

Long history of formation of community groups, through the journey is not easy and not instant. The journey that at a certain point left a trace recorded up to now in the form of cultural heritage. Cultural heritage, according to Davidson (1991) in Karmadi (2007) is defined as a product or a result of the physical culture of different traditions and spiritual achievements in the form of values from the past which became the key element in 
the identity of a group or nation that established local wisdom.

According Koentjaraningrat (1985), local cultural values in the realm of culture can be incarnated in various forms such as; ideas, values, norms, and rules. Whereas in social life can be religious system, system and social organization, knowledge system, livelihood system, and technology system / equipment.

Local wisdom in the study of Anthropology as a local genius was first introduced by Quatrich Wales (Ayatrohaedi, 1986 in Sartini, 2004). While local genius in the context of cultural psychology is also referred to as a cultural identity (cultural identity) that causes a nation is able to absorb and cultivate foreign culture according to the character and ability itself. Local wisdom places more emphasis on the positive ability of the ultimate life values that are owned, believed and usually still done in everyday life by each community (Sulastri, 2007).

According to Ridwan (2007), substantially local wisdom is the values prevailing in a society, so it is reasonable if local wisdom is an entity that determines the dignity and human dignity of the community.

Social capital includes acceptable values and norms reflected in the interaction between individuals of any society, company or organization (Mahmood, 2015). Social capital is often referred to as local wisdom. Local knowledge possessed by an organization (group of individuals) can not be assessed in financial, local knowledge is seen as intangible assets non-financial (nonfinancial intangible assets)are valuable.

The study of non financial intangible assets in the last few decades attracted many intellectuals. This interest is based on empirical evidence that non-financial intangible assets owned by an organization contribute to increasing the potential of organizational innovation and ultimately can improve organizational performance for the better (Mahmood 2015). Other contributions are described by Flora (2004) in Surata et al. (2014) that social capital has a relationship with all types of capital categorized in community capital, including natural capital, built capital,cultural capital,financial capital), human capital, and political capital. Local wisdom plays a role in facilitating the birth of new knowledge and creating added value for the organization so as to ensure the sustainability and development of the organization.

The concept of sustainability in Kulham (2010) stems from the approach of forestry science, which emphasizes efforts to harvest forest products adapted to the ability of forests to provide their production capacity. The word nachhaltigkeit (German for sustainability) means the effort to preserve natural resources for the future. Taking into account the preservation of nature means maintaining the continuity that emphasizes the harmonization between man and nature.

Sustainability is always seen from three dimensions namely; social, economic and environmental issues. The definition of sustainability in Kulham (2010) adopted from the United Nations on the development agenda: Development is a multidimensional undertaking to achieve a higher quality of life for all people. Economic development, social development and environmental protection are interdependent and mutually reinforcing components of sustainable development.

Another meaning of sustainability as Solow's (1991) economist in Whitehead (2006) in Susanto and Tarigan (2013) suggests sustainability as a result of society that allows future generations to at least retain the same natural wealth as the present generation. at least as good as the current generation.

In the local wisdom governance in support of sustainability for the organization can be described as in Figure 1 framework of thinking. 


\section{Figure 1. Framework of Thinking}

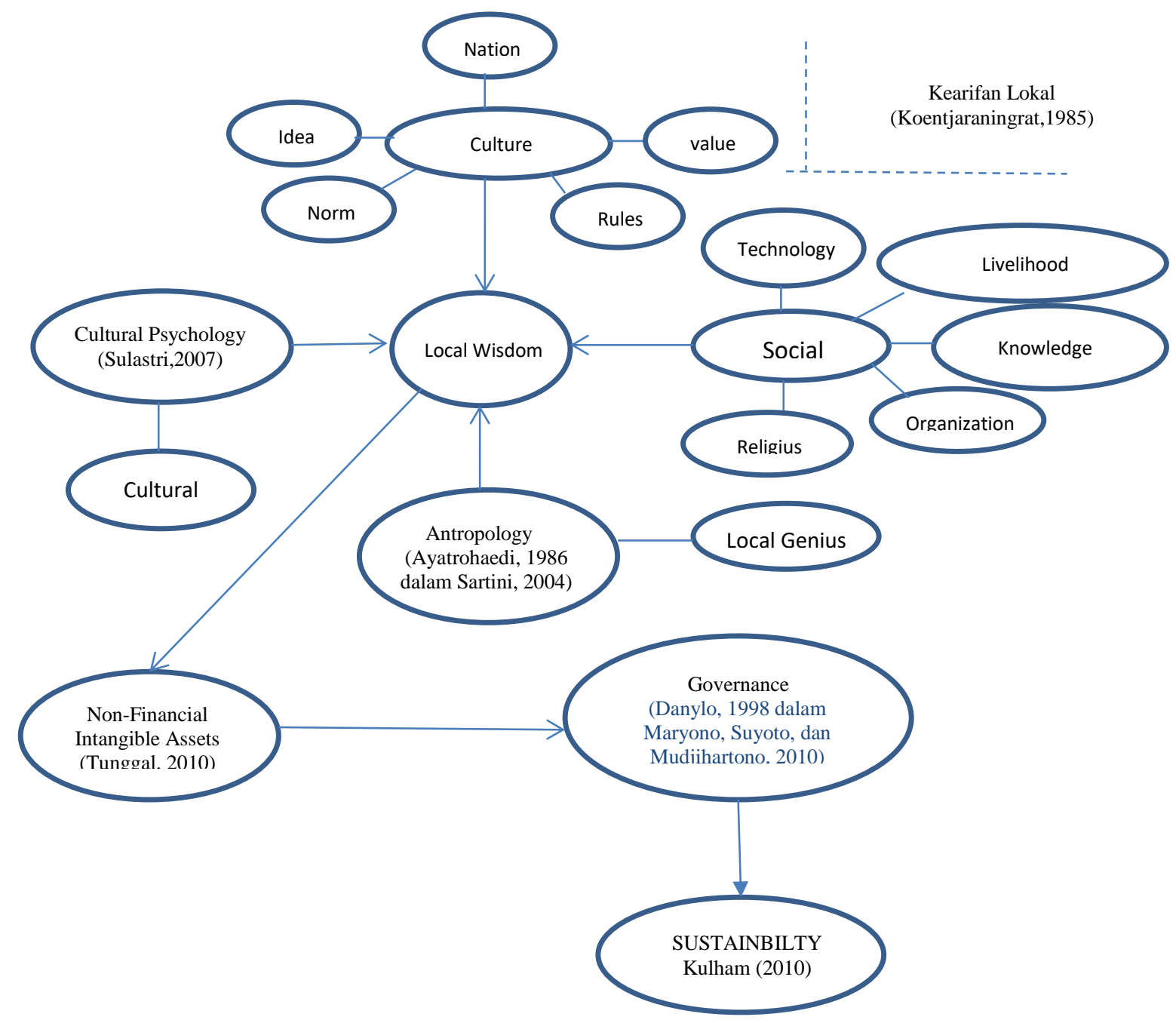

\section{Research Methods}

The method used in this research is qualitative method with interpretive paradigm and phenomenological approach. According to Sudarma (2010), qualitative methods are also called constructivist or naturalistic approaches. There are two basic reasons for the use of qualitative approaches in this research: first, to explore and understand the meaning of the object of research from individuals or groups deemed to be derived from social or humanitarian problems. Second, data acquisition can be more complete, deeper and more reliable, and all events in a social context that include feelings, norms, beliefs, habits, attitudes, and cultures embraced by individuals and groups of individuals can be found (Creswell, 2010) .
This research is included in the realm of interpretive paradigm. This is based on research objectives that explores the understanding of informants about the governance of assets and sustainability of indigenous villagers of Kampung Pulo Garut district and the underlying values. According to Burrell and Morgan (1994), states interpretive paradigms view humans as free beings, independent, and able to create social world, ideas, concepts, and theories. This social reality is seen as relative because it is formed through interaction between humans.

The use of phenomenology is based on the purpose of this study understanding the implementation of the value of wisdom existing in the Kampung Pulo Garut Regency and 
explore the value of such wisdom as non financial intangible assets in governance assets and sustainability organization. Qualitative research using phenomenology approach aims to bring awareness and deep understanding about how human experience something (Saldana, 2011). The phenomenological approach, giving more attention to the description of the object of a concept as well as a phenomenon (Creswell 2007). Moustakas (1994) positioned phenomenology as an effort to show itself in order to make things clearer and clearer.

Phenomenology in term can be understood as a stream that speaks of phenomena or phenomena or anything that appears and what appears to be self. Phenomenology views communication as a process of sharing the informant's personal experience through the flow of dialogue or conversation and its significance with the aim of discovering and expressing a deep awareness and understanding of how humans experience something (Musmini, Sirajudin, 2016).
In the history of Kampung Pulo, the authors conducted in-depth interviews of the three informants who are considered most aware of the history and the existence of Kampung Pulo. To support other data on this history, the authors also include secondary data derived from previous studies published in scientific journals.

\section{Result and Discussion}

Local wisdom that is owned by indigenous people of kampung pulo, until the research done mostly still adhered and preserved by community member. This proves that the indigenous people are able to manage the wisdom amid the onslaught of modernization. They have the belief that by preserving the wealth of traditional and cultural customs by sticking to Islam as their creed, the welfare of life they hope will be achieved. In researching the local wisdom, the following diagram of governance based on the results of observations and interviews in the field.

Figure 2. Flowchart Interview Local Wisdom

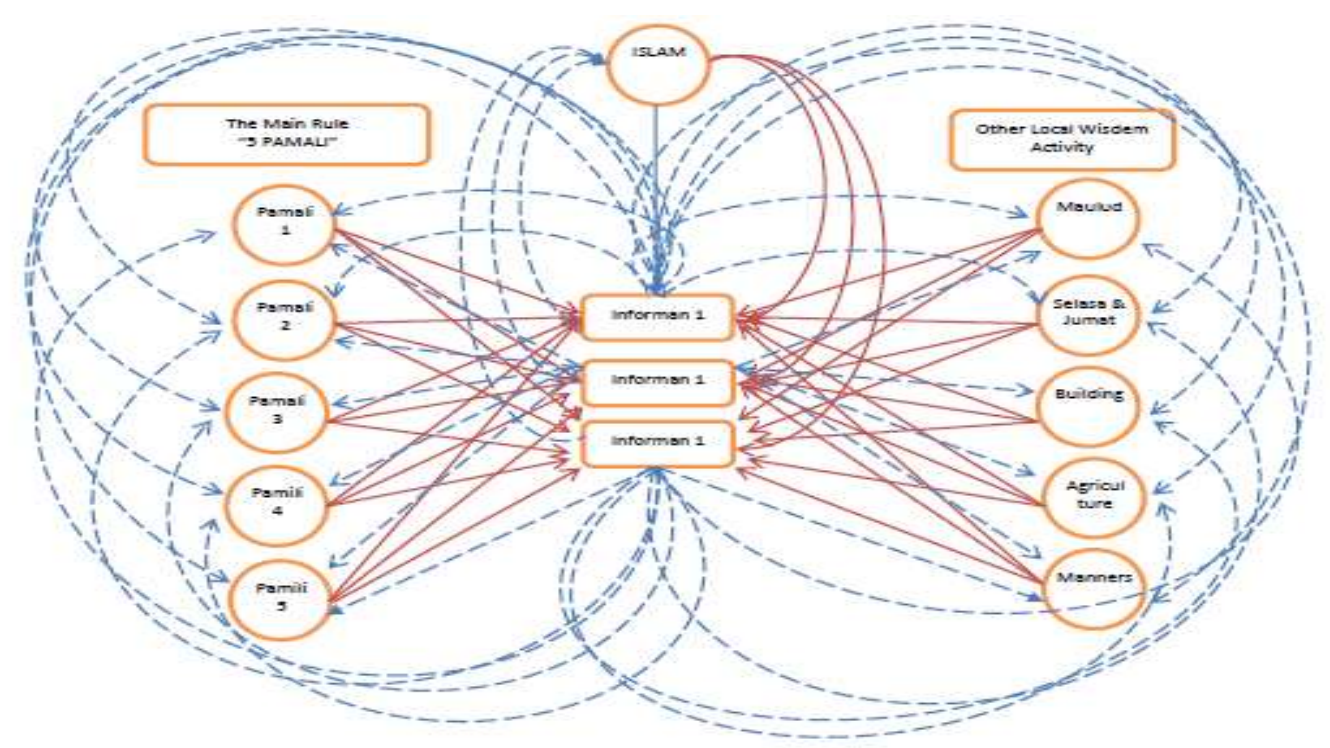

Remarks:

Line of Question to Informan Line of Answer from the Informant 
Islam is a religion that is embraced by all members of the indigenous community of Kampung Pulo which became the main foothold and the highest view of life in the customs and rules prevailing in society. Arif Muhammad as the direct ancestor and founder of the village of Pulo is a Muslim and as a spreader of Islam in the region Cangkuang.

In the spread of Islam, he uses a cultural approach. The reason through the cultural approach, because Cangkuang is a region dominated by Hindu society and strong animism. Cultural approach is the spread of Islam by using the prevailing cultures in society. With this cultural approach, Islam can be accepted by society. In practice, things that are shirk are removed, while the habit is only used as a culture only. These cultural practices which are local wisdom of Kampung Pulo society are greatly influenced by the philosophies in Islam.

Five Pamali is the most important local wisdom in the indigenous communities of Kampung Pulo disampaing other bans that are still valid and implemented. The sustainability and obedience of the community members to the Five Pamali is still guaranteed. Five Pamali are Five restrictions that should not be violated by members of the community. Violation of the prohibition does not lead to formal sanctions, but rather on adat sanctions that focus on social sanctions. Five Pamali in the Pulo village community consist of: (1) Must not hit the big gong; (2) Should not make the roof of the house in the form of jure / prism; (3) Can not keep fourlegged animals; (4) No pilgrimage on wednesday; (5) Can not increase or decrease the main building.

The meaning of the ban on gong or goong means that the indigenous people of Pulo village must always be in simplicity, in gentleness and avoiding arrogance. Meaning of should not make the roof of the house in the form of jure / prism, the people of Kampung Pulo must unite, should not divorce and always have to protect each other among the members of the community. Meaning of should not keep the animals four-legged, that the people of Pulo village must love the environment and the natural surroundings. The relationship between humans and nature that equally as God's creatures will provide balance and benefit for both in maintaining continuity. The meaning of should not be on pilgrimage on Wednesday, that this prohibition is related to time management. Activities within a week should not always look for a worldly relationship, but also have to search about to the Close. Meaning of should not increase or decrease the main building, giving meaning that people should always act honestly in words and actions. Community members must always convey the truth, should not be added and should not be reduced.

From the results of the above research that Islam is a religion that is embraced by all members of the village community of Pulo. The existence of Islam as a religion in the base by his ancestor that is Arif Muhammad as founder of Pulo village and spreader of Islam in Cangkuang region.

Islam entered the Cangkuang region through a cultural approach, so that the previous people embraced Hinduism, animism, and dynamism gradually accepted Islam as its religion. This cultural approach by not erasing directly the existing culture, but incorporating the teachings of Islam in an existing culture by removing the thoughts and feelings of associating God within them.

From the results of observations and interviews with informants, it can be explained that the Local Wisdom is a Non Financial Intangible Assets owned by villagers Pulo result from 
the acculturation between local culture with Islam as a new religion.

It can be seen that the activities of indigenous peoples are still influenced by the previous culture (Hinduism, Animism, Dynamism) but the emergence of Islamic activities in it as a complement.

From the results of cultural acculturation with the Islamic religion emerged local wisdom that is full of philosophy and rules as a foothold in the life of society. This local wisdom consists of two parts: (1) The Wisdom of Philosophy which is reflected in the "Five Pamali", (2) Wisdom Activity, this wisdom is reflected in the daily activities of Pulo villagers who are active in religious, economic and social aspects.

Four centuries is a time that has a very long range. The survival of an organization that can survive for a century of achievement. The indigenous people of the village of Pulo are able to maintain their survival up to now for four centuries.

Governance is a major factor in maintaining sustainability. The indigenous people of Pulo village are able to manage their local wisdom with the distinctive characteristics of their management.

From the research results, it can pull the red thread of governance done by indigenous villagers pulo into four:

1. Exemplary adat chairman. Exemplary is the main factor that gives the people compliance with local wisdom. This is shown by the behavior and lifestyle of traditional chairman and vice chairman of adat in daily life.
2. Communication. Communication will break down all the problems faced by community members. Communication between community members has a high enough intensity of every activity of local wisdom, because every activity of local wisdom in it contains communication philosophy.

3. Knowledge. Knowledge of local wisdom is informally conveyed. The involvement of all members of the community in every activity of local wisdom, provides direct knowledge of local wisdom practices. This process provides awareness of the importance of local wisdom and gives a strong impression in the community.

4. Remind each other. In the indigenous peoples neighborhood there is no formal sanction, only social sanctions. Adherence to local wisdom is done by always reminded by traditional chairman and also remind each other among community members. The intensity of mutual reminiscence is high enough to always be delivered within the same set of activities of local wisdom.

From the style of governance above, the adherence of indigenous members of indigenous villages can be relied upon to be able to inherit local wisdom that became its own characteristics.

From the description above can be described the flow of local wisdom governance conducted by villagers of Pulo in maintaining its continuity as follows: 
Figure 2. Diagram Alur Tata Kelola Kearifan Lokal

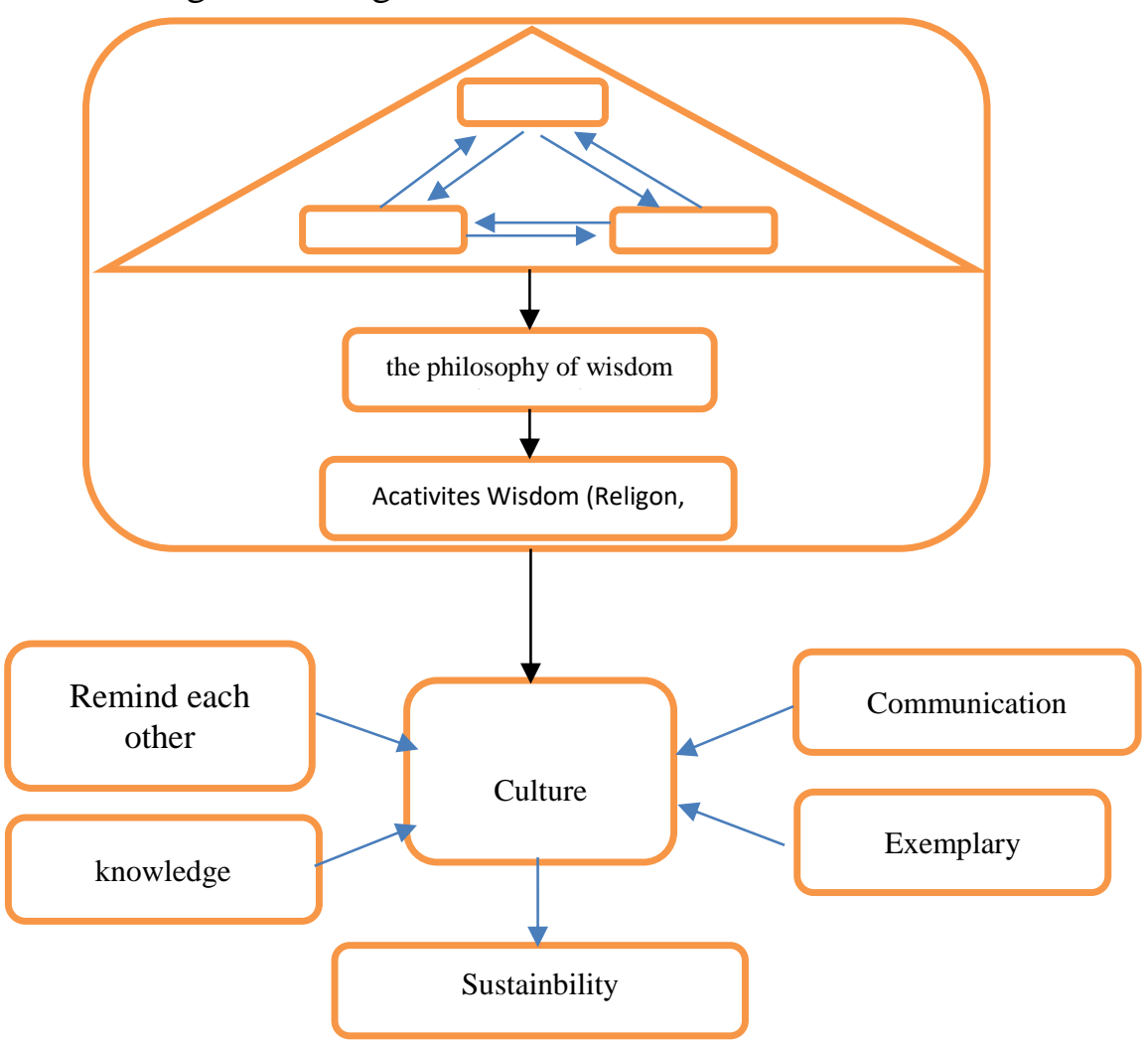

\section{Conclusion}

From the results of research and discussion in the previous chapter, it can be drawn conclusions as follows:

1. Local wisdom indigenous villagers pulo, is the result of acculturation local culture before the Islamic religion comes with the teachings of Islam in it that contains the philosophy of life and teaches the balance between human beings with humans, manuasia with God, and humans with Nature.

2. Local wisdom can be divided into two, namely the wisdom of the philosophy with "Five Pamali" and the wisdom of activities related to economic, social, cultural, all of which are Non Financial Intangible Assets.

3. Local wisdom governance is transformed in the form of exemplary, communication, education, and intensive reminding each other in every activity.
4. Local wisdom, which is Non Financial Intangible Assets, if managed with a model of management conducted by the indigenous villagers Pulo will have an impact on sustainability.

\section{Acknowledgments}

We would like to thank the Directorate of Research and Community Service (DRPM), the Ministry of Research, Technology and Higher Education, Indonesia who has funded this research grant through a novice lecturer research scheme for the fiscal year 2018.

\section{References}

Amalilah. 2016. Nilai-Nilai Budaya Tri Hita Kirana dalam Penetapan Harga Jual. Jurnal Akuntansi Multiparadigma. Vol. 7, No. 2, hlm 189-206

Burrel, G. dan G. Morgan. 1994. Sociological Paradigms and 
Organizational Analysis:

Elements of the Sociology of Corporate Life. Penerbit Arena. England.

Cresswell, J. W. 2007. Qualitative Inquiry and Research Design:Choosing among Five Approaches, Sage Publications. London.

Cresswell, J. W. 2010. Research Design: Qualitative, Quantitative, and Mix Methodes Approach, Achmad Fawaid (Penerjema). Research Design: Pendekatan Kualitatif, Kuantitatif, dan Mixed, Pustaka Pelajar. Yogyakarta.

Hasbiansyah O. 2008. Pendekatan Fenomenologi: Pengantar Praktik Penelitian dalam Ilmu Sosial dan Komunikasi, MEDIATOR, Vol. 9 No.1, hlm 163-180

Karmadi, A. D., 2007, Budaya Lokal sebagai Warisan Budaya dan Pelestariannya, Semarang: Dinas Pendidikan dan Kebudayaan Propinsi Jawa Tengah.

Koentjaraningrat. 1985. Pengantar ilmu Antropologi, Jakarta: Aksara Baru

Kulham Tom, Farrington John. 2010. What is Sustainability?. Sustainability.Vol. 2, hlm 3436-3488. doi:10.3390/su2113436

Kuswara Nanang. 2016. "Rephilosophizing Islam Education Towardsocial Changeat Kampung Adat Pulo, Situ Cangkuang, Garut,West Java”. Proceedings. The 2nd International Multidisciplinary Conference. Universitas Muhammadiyah Jakarta, Indonesia. ISBN 978-60216688-9-1.hlm 1195-1200

Mahdalena Niswatin. 2016. Nilai Kearifan Lokal "Subak" sebagai Modal Sosial
Transmigran Etnis Bali. Jurnal Akuntansi Multiparadigma. Vol. 7, No. 2, hlm 171-188

Maryono Y, Suyoto, Mudjihartono Paulus. 2010. Analisis Dan Perancangan Sistem Informasi Manajemen Aset TIK Studi Kasus: Asmi Santa Maria Yogyakarta. Jurnal Buana Informatika, Volume 1, No. 2, Juli, hlm 81-90

Moustakas $\quad$ Clark. 1994.

Phenomenological Research

Methods. Sage

Publications.Thausand Oaks

California.

Musmini. dan Irajudin. 2016. Makna Akuntansi Sosial dan Sustainabilitas Sekaa Suka Duka. Jurnal Akuntansi Multiparadigma, Vol. 7, No. 2, hlm 156-170

Niswatin dan Mahdalena. 2016. Nilai Kearifan Lokal "SUBAK" Sebagai Modal Sosial Transmigran Etnis Bali. Jurnal Akuntansi Multiparadigma, Vol. 7, No. 2, hlm 171-188.

Ouertani, Mohamed Zied, et al.,2008. "Towards An Approach To Select An Asset Information Management Strategy", International Journal Of Computer Science And Applications, vol. 5, no. 3b, hlm 25-44

Ramdianti Nurliana, Hidayah Apriliana Hexa, dan Widyawati Yayu. 2013. Kajian Etnobotani Masyarakat Adat Kampung Pulo di Kabupaten Garut. Jurnal Biosfera.hlm. Vol.30 No. 1. hlm 38-50

Saldana, J. 2011. Ethnotheatre: Research from page to stage (Edisi 3): Left Coast Press. New York.

Sartini. 2004. Menggali Kearifan Lokal Nusantara Sebuah Kajian Filsafati, Jurnal Filsafat, 
Agustus, Jilid 37, No.2, hlm 111-119

Sudana, I Putu. 2014. Teori Stukturasi dan Akuntansi Sustainabilitas. Jurnal Ilmiah Akuntansi dan Bisnis. Vol. 9 No. 2, hlm 111121

Sudarma, M. 2010. Paradigma Penelitian Akuntansi dan Keuangan. Jurnal Akuntansi Multiparadigma, Vol. 1, No. 1, hlm 97-108

Sugeng Triyadi dan Andi Harapan. 2009. Kearifan Lokal Rumah Venacular Di Jawa Barat Bagian Selatan dalam Merespon Gempa. EMAS Jurnal Sains dan Teknologi, Vol. 18, No. 2, hlm 123-134

Sulastri, Augustina. 2007. Kearifan Lokal Jawa dan Resiliensi Terhadap Trauma Psikologis Pada Korban Selamat Bencana Gempa Bumi di Bantul, Yogyakarta, Jurnal Kajan Politik Lokal dan SosialHumaniora, Vol. 4 No. 1, hlm 146-166

Susanto Yohanes kurniawan, Tarigan Josua. 2013. Pengaruh Pengungkapan Sustainability Report terhadap Profitabilitas Perusahaan. Business Accounting Riview. Vol. 1

Syukur Abdul.2016. Kampung Pulo: Traces of Islamic Culture in Garut Regency, West Java. SASDAYA, Gadjah Mada Journal of Humanities , Vol. 1, No. 1, hlm 34-52

Tri Kusumawati1, Ari Widyati Purwantiasning, Anisa, Seminar Nasional Sains dan Teknologi 2015 Fakultas Teknik Universitas Muhammadiyah Jakarta, 17 November 2015, Website : jurnal.ftumj.ac.id/index.php/se mnastek
Tunggal Amin Wijaya. 2010. Accounting for Intangible Assets. Harvarindo. Jakarta.

Z Mumuh Muhsin. (2010). "Penyebaran Islam di Jawa Barat". Makalah disampaikan dalam Saresehan Nasional "Sejarah Perjuangan Syaikhuna Badruzzaman (1898-1972)". Di Pondok Pesantren Al Falah, Mekargalih, Tarogong Kidul, Kabupaten Garut. http://pustaka.unpad.ac.id/wpcontent/uploads/2012/05/pustak a_unpad_penyebaran_islam_di jawa_barat.pdf 